\title{
Metode Godfrey vs Sherwood-Rout dalam Animasi Profil Program pada Lembaga Amil Zakat Solopeduli
}

\author{
Hanifah Permatasari ${ }^{1}$, Indah Nofikasari ${ }^{2}$, Zeno Candragufa Muria ${ }^{3}$ \\ Universitas Duta Bangsa ${ }^{1,2,3}$ \\ hanifah_permatasari@udb.ac.id ${ }^{1}$, indah_nofika@udb.ac.id ${ }^{2}$, zenocandragufa@gmail.com³
}

\begin{abstract}
Abstrak - Lembaga Amil Zakat (LAZ) Solopeduli merupakan organisasi nirlaba berbasis pilantropi yang bertugas dalam pengelolaan zakat. Sama seperti organisasi profit, LAZ berusaha untuk mempromosikan program unggulannya, dengan memanfaatkan konten-konten multimedia untuk disebar melalui media sosial. Permasalahannya, belum semua program LAZ telah ada konten multimedianya. Apabila LAZ hendak membuat sebuah konten profil program berbasis multimedia, maka LAZ harus mempertimbangkan metode pengembangan sistem. Hal ini berkaitan dengan keterbatasan sumber daya manusia, waktu, dan keuangan lembaga yang dialokasikan untuk pengembangan. Minimnya penelitian terdahulu tentang konten multimedia pada LAZ, serta belum adanya pembahasan mendetail soal penerapan metode pengembangan multimedia, maka penelitian ini dilakukan untuk memberikan kontribusi baru dalam bidang multimedia di Indonesia. Penelitian ini memilih metode Godfrey dan metode Sherwood-Rout untuk dieksekusi, karena keduanya merupakan metode terstruktur, namun memiliki fokus yang berbeda dalam pengembangan. Penelitian ini bertujuan untuk mengetahui bagaimana metode Godfrey dan metode Sherwood-Rout dapat mengembangkan profil program organisasi nirlaba, dan apa perbedaan yang diperoleh dari kedua metode tersebut dalam kasus ini. Hasilnya, penelitian ini telah menemukan tiga fokus utama yang dapat memberikan referensi kapan dan dalam situasi apa metode tersebut akan tepat digunakan.
\end{abstract}

Kata Kunci: Godfrey Sherwood-Rout, Lembaga Amil Zakat, Animasi Program, Multimedia

\begin{abstract}
The Amil Zakat Institute (LAZ) Solopeduli is a non-profit organization based on pilantropy which involves zakat management. Like profit organizations, LAZ strives to promote its flagship programs, utilizing multimedia content to be disseminated through social media. The problem is, not all LAZ programs have multimedia content. If LAZ wants to create multimedia-based profile program content, then LAZ must consider the system development method. This is related to the human resources, time, and financial institutions that are allocated for development. The lack of research on multimedia content at LAZ, and there has been no detailed discussion about the application of multimedia development methods, so this research was conducted to make new contributions in the field of multimedia in Indonesia. This study chose the Godfrey method and the Sherwood-Rout method to be executed, because it is a structured method, but has a different focus in development. The Godfrey research method and the Sherwood-Rout method can develop a nonprofit organization's program profile, and what are the differences obtained from the two methods in this case. The results, this study has found three main focus that can provide a reference at any time and in discussion what this method would be appropriate to use.
\end{abstract}

\section{Keywords: Godfrey Sherwood-Rout, Lembaga Amil Zakat, Program Animations, Multimedia}

\section{PENDAHULUAN}

Saat ini, multimedia sedang menjadi tren alat promosi baik untuk organisasi berorientasi laba maupun organisasi nirlaba. Organisasi berorientasi laba membutuhkan multimedia sebagai alat untuk penyediaan informasi sekaligus mempromosikan barang dan jasa (Maimunah et al., 2012). Tujuannya untuk menarik minat dan daya beli masyarakat, sehingga barang dan jasa yang tersedia dapat laku terjual (Haryanto \& Nugroho, 2015; Sunarya, Lusyani; Radiyanto; Susanti, 2013). Berbeda dengan organisasi nirlaba, organisasi ini membutuhkan multimedia sebagai alat untuk menarik kepercayaan publik (Hartono, 2018;
Satryadi, 2016), atau memudahkan masyarakat dalam memahami sebuah simulasi atau pembelajaran (Arfan et al., 2010; Suartama, 2010).

Salah satu jenis organisasi nirlaba di Indonesia adalah Lembaga Amil Zakat (LAZ). LAZ merupakan organisasi pengelola zakat yang berasal dari komunitas, organisasi, atau yayasan masyarakat. Lembaga tersebut memiliki berbagai program penyaluran dan pendayagunaan zakat, infaq, dan sedekah ( $P$. N. R. Indonesia, 2014). Obyek pada penelitian ini adalah LAZ Solopeduli. LAZ ini merupakan LAZ Provinsi, dan telah berdiri sejak tahun 1999. 
LAZ Solopeduli selalu memasarkan programprogram unggulannya, sebab melalui programprogram inilah LAZ Solopeduli akan lebih banyak melakukan aktivitas sosial, sehingga keberadaannya akan lebih dikenal oleh masyarakat. Hal ini penting, sebab bagi organisasi nirlaba, program layanan publik, dan program-program serupa merupakan salah satu sumber pendanaan lembaga (Hackler \& Saxton, 2007). Media sosial seperti Instagram, WhatsApp, dan Facebook telah termanfaatkan untuk mengoptimalkan jangkauan pemasaran. LAZ Solopeduli telah membuat beberapa konten, mulai dari konten-konten gambar yang disebarkan melalui akun media sosial, sampai pada konten animasi dan video yang diunggah pada akun Youtube. LAZ Solopeduli sangat berusaha mengoptimalkan kegiatan pemasaran berkaitan program yang dimiliki, dengan membuat konten multimedia, mengingat konten seperti ini jauh lebih sederhana dan cepat diterima oleh masyarakat. Namun sampai saat ini, hanya sedikit program LAZ yang telah memiliki profil berbasis multimedia.

Berkaitan dengan teknologi yang dapat menginformasikan mengenai program unggulan LAZ, beberapa penelitian terdahulu juga telah mengembangkannya. Tetapi, informasi tersebut tidak dibuat dalam bentuk multimedia yang kompatibel untuk diunggah pada media sosial. Informasi tersebut dikembangkan dalam sebuah aplikasi genggam, website, dan sistem informasi (Aisyah, 2010; Dara et al., 2018; Gufroni et al., 2014; Herdiyansyah et al., 2013; Novansyah et al., 2016). Sementara untuk pengembangan multimedia, penelitian terdahulu berfokus pada edukasi, bukan pada konten profil program LAZ. Maksud dari profil program adalah definisi, atau informasi tentang sebuah program unggulan LAZ. Diantaranya adalah Fatoni dan Puspitasari (2016) membuat Perancangan Simulasi Pengembangan Sistem Programming Penyaluran Dana Zakat di Badan Amil Zakat Kota Serang Berbasis Multimedia. Penelitian ini menggunakan metode RAD, dan bertujuan untuk merancang sebuah simulasi yang memberikan informasi terkait penyaluran dana zakat, mengingat salah satu aspek yang mempengaruhi perolehan kepercayaan publik badan/lembaga zakat adalah penyaluran. Khair (2011) melakukan penelitian yang mengembangkan aplikasi multimedia berbasis mobile di LAZ Al Azhar Peduli Ummat. Penelitian tersebut menggunakan metode Luther, dan bertujuan untuk menghasilkan aplikasi yang mampu memberikan informasi seputar zakat, serta kemudahan dalam perhitungannya.

Apabila LAZ hendak membuat sebuah konten profil program berbasis multimedia, maka LAZ harus mempertimbangkan metode pengembangan sistem. Metode pengembangan multimedia merupakan suatu hal yang sangat penting dipertimbangkan oleh LAZ, mengingat tidak banyak sumber daya manusia di LAZ yang memahami konten ini. Metode akan memberikan kejelasan pada organisasi berkaitan dengan alur pembuatan animasi, mulai dari analisis sampai selesai. Hal ini akan mengondisikan LAZ untuk menentukan anggaran, dan mengoptimalisasi sumber daya manusia untuk terlibat pada masing-masing tahapnya, sehingga animasi yang dihasilkan akan sesuai ekspektasi organisasi. Capaian ekspektasi ini merupakan tekanan tersendiri bagi LAZ, sebab anggaran pembuatan animasi tersebut berasal dari sumber daya yang harus dipertanggung jawabkan. Sumber daya organisasi nirlaba diperoleh dari para donatur yang tidak mengharapkan pembayaran kembali atau pengembalian manfaat ekonomi yang sebanding dengan jumlah sumberdaya yang diberikan (I. A. Indonesia, 2011).

Salah satu metode pengembangan multimedia yang paling populer di Indonesia adalah Metode Luther. Metode ini bersifat linier seperti metode Godfrey, akan tetapi tidak lebih detail daripada Godfrey. Analisis pada metode Luther masuk dalam tahap Concept, sedangkan analisis pada metode Godfrey masuk dalam dua tahap yaitu Problem Definition, dan Genre and Character. Masingmasing tahap pada metode Godfrey dan Luther tidak menekankan pada review dari client. Artinya, multimedia yang telah didiskusikan sejak awal secara detail, maka asumsi pengembang adalah benar, sehingga multimedia yang dihasilkan dapat diterima langsung oleh client.

Hal ini berbeda dengan metode pengembangan Sherwood-Rout. Metode ini juga merupakan metode linier seperti Luther dan Godfrey, namun metode Sherwood-Rout ini lebih fokus pada penggalian review dan pengujian pada client, terlebih sebelum multimedia digunakan oleh client. Pada beberapa kasus, pengujian pada metode Godfrey lebih sulit dilakukan dibanding metode Sherwood-Rout. Hal ini dikarenakan pengembang selalu melakukan evaluasi bersama client pada metode Sherwood-Rout, sedangkan pada metode Godfrey tidak demikian. Berkaitan dengan manakah metode yang lebih tepat, tidak ada referensi mengenai hal tersebut. Hal ini dikarenakan banyak faktor yang mendukung keberhasilan penggunaan metode, diantaranya waktu, pendanaan, struktur pengembang, dan karakter client (Binanto, 2013).

Penelitian ini memilih metode Godfrey dan metode Sherwood-Rout untuk mengembangkan dua profil program LAZ 
Solopeduli. Tujuannya adalah untuk mengetahui bagaimana kedua metode tersebut dapat mengembangkan profil program organisasi nirlaba, dan apa perbedaan dari kedua metode tersebut dalam kasus ini.

\section{METODOLOGI PENELITIAN}

Tahap penelitian ditampilkan pada Gambar 1.

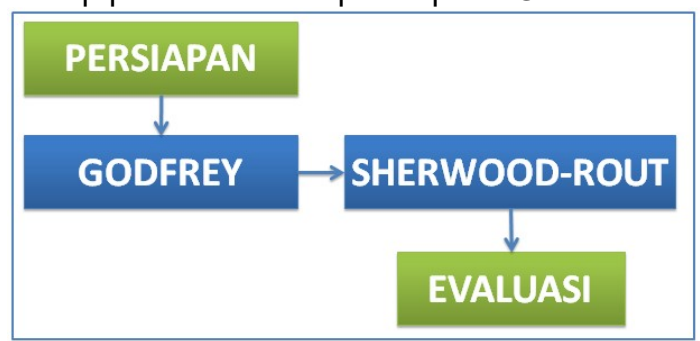

Gambar 1. Tahap Penelitian

\section{Persiapan}

Tahap persiapan adalah tahap pemilihan proyek program yang akan dikerjakan bersama LAZ. Pada awal pertemuan, peneliti menjelaskan secara detail kepada client mengenai Metode Godfrey dan Metode Sherwood-Rout, kemudian client memilih satu program yang menurut LAZ sesuai untuk diselesaikan dengan Metode Godfrey, dan satu program lainnya yang menurut LAZ sesuai untuk diselesaikan dengan Metode SherwoodRout. Peneliti tidak memberi masukan apapun mengenai pemilihan proyek program karena peneliti tidak memiliki keberpihakan terhadap salah satu metode, sehingga ide pemilihan proyek program adalah seratus persen berasal dari LAZ.

\section{Metode Godfrey}

Nama lain dari metode ini adalah Multimedia Development Life Cycle (MDLC). Metode ini merupakan metode pengembangan perangkat lunak klasik yang dikenal dengan Waterfall, akan tetapi khusus pada konteks multimedia (Godfrey, 1995). Tahapan dari metode ini adalah :

\section{a. Problem Definition}

Tahap ini peneliti mengidentifikasi LAZ, melakukan komunikasi untuk mendapatkan kebutuhan, mengidentifikasi antara seberapa besar proyek program yang akan dikerjakan dan kesesuaian jadwal, serta memahami keterbatasan sumber daya yang ada.

b. Genre and Character

Berdasarkan kebutuhan yang diperoleh pada tahan pertama, peneliti menguraikan alur animasi yang tepat untuk menggambarkan program LAZ. Adapun batasan-batasan yang tidak boleh dilampaui oleh peneliti, diberikan oleh LAZ pada tahap ini.

c. Location and Interface

Peneliti membuat sketsa side by side terkait bagaimana animasi tersebut akan ditampilkan.
Sketsa location multimedia ditekankan bukan pada penggambaran yang akurat, tetapi pada penggambaran esensi dari beberapa aktivitas (Binanto, 2013). Adapun aktivitas yang dimaksud dalam kasus ini adalah bagaimana "bahasa dan desain" pemasaran yang saat ini dilakukan oleh LAZ untuk mempromosikan program tersebut.

\section{d. Plotting}

Tahap ini adalah proses peletakan material konten pada frame dan layer, sesuai dengan jalan cerita yang ditentukan pada tahap sebelumnya. Adapun peletakan ini menggunakan software Adobe After Effect.

\section{e. Scripting}

Scripting adalah proses mendefinisikan semua dialog, dan seluruh interaksi. Pada istilah yang lain, tahap ini disebut coding suatu program (Binanto, 2013).

\section{f. Production and Testing}

Animasi yang telah diproduksi akan diuji pada tahap ini. Peneliti memastikan tidak ada tulisan yang salah, bug, atau ada sisipan konten yang terlarang menurut $L A Z$ dalam animasi tersebut. Setelah lolos uji, maka animasi siap diunggah pada Highlight Instagram.

\section{Metode Sherwood-Rout}

Sherwood \& Rout (1998) menjelaskan ada enam tahap dalam pengembangan multimedia. Tahp tersebut adalah :

a. Project Initation

Tahap ini fokus pada rencana kebutuhan pengembangan animasi. Peneliti melakukan komunikasi terhadap client guna menganalisis karakteristik program yang akan dibuat dan karakteristik dari LAZ itu sendiri.

b. Specifications

Tahap ini membahas detail penyusunan animasi, mulai dari alur, logo, background dan lata musik. Pembahasan ini diawali dengan sketsa dan deskripsi, tentang bagaimana animasi yang akan dibuat mampu mendefinisikan program.

\section{c. Design}

Peneliti membuat desain side by side tampilan animasi. Desain ini dikomunikasikan dengan client, apakah sudah tepat atau mengalami perbaikan.

\section{d. Production}

Animasi dibuat berdasarkan desain. Semua material penyusun mulai diatur pada frame dan layer.

e. Review and Evaluation

Animasi yang telah dibuat akan dilihat oleh client, kemudian terjadi diskusi apakah animasi yang telah dihasilkan sudah sesuai atau belum. f. Delivery and Implementation

Animasi yang telah sesuai dengan kebutuhan client siap untuk diunggah pada highlight Instagram. 


\section{Evaluasi}

Hasil penerapan kedua metode dievaluasi bersama client, baik animasi yang dihasilkan maupun metode pengembanganya. Evaluasi dilakukan dengan pendekatan interpretif. Pendekatan ini memungkinkan peneliti bertanya mengenai ketepatan ekspektasi animasi yang dihasilkan, mengingat sumber daya manusia pada LAZ Yayasan Solopeduli Ummat tidak berasal dari latar belakang multimedia. Selain itu, pada tahap evaluasi ini peneliti akan menganalisis perbandingan kedua metode yang digunakan. Pendekatan ini dipilih karena dapat sebagai sarana yang berguna untuk meneliti dan memahami fenomena organisasi yang kompleks dan ambigu (Nordqvist et al., 2009). Selain itu, pendekatan ini juga tepat untuk menyelidiki lebih lanjut dan memahami perbedaan dalam populasi heterogen (Melin \& Nordqvist, 2007), sehingga mudah untuk menghasilkan temuan terkait penggunaan dua metode yang berbeda dari berbagai persepektif.

\section{HASIL DAN PEMBAHASAN}

\section{Penerapan Metode Godfrey dan Metode Sherwood-Rout}

Pada bagian pertama ini, akan dijelaskan hasil dari animasi yang dihasilkan dari penggunaan metode Godfrey dan metode Sherwood-Rout.

\section{a. Persiapan}

Peneliti melakukan diskusi bersama LAZ Solopeduli tentang pemilihan proyek program dan metode pengembangannya. Adapun narasumber dalam penelitian ini merupakan Manajer Fundraising Pusat. Sasaran penelitian ini dapat terpenuhi, sebab narasumber ini membawahi segala kegiatan Fundraising pada seluruh kantor area Solopeduli, termasuk Fundraising yang dilakukan secara daring dan sangat memahami pentingnya konten pemasaran bagi LAZ.

Setelah narasumber memahami tahapan dari masing-masing metode pengembangan, narasumber melakukan diskusi dengan Direktur Pelaksana Pusat guna memilih proyek program yang sesuai untuk diselesaikan dengan kedua metode. Pilihan LAZ Solopeduli dapat dilihat pada Tabel 1.

Tabel 1. Proyek Program dan Metode

\begin{tabular}{cc}
\hline Proyek Program & Metode \\
\hline Akikah Peduli & Godfrey \\
Super Sedekah & Sherwood-Rout \\
\hline
\end{tabular}

\section{b. Metode Godfrey}

Program "Akikah Peduli" merupakan salah satu program Solopeduli yang memiliki ketentuan cerita penyajian di dalamnya. Adapun tahap pengembangan animasi program tersebut adalah sebagai berikut:

1) Problem Definition

LAZ Solopeduli merupakan LAZ Skala Provinsi yang terdiri dari delapan area operasional. LAZ Solopeduli memiliki akun Instagram yang digunakan untuk menjalin hubungan dengan para mitra dan donaturnya. Adapun media vital dalam Instagram adalah gambar dan video. Menurut pemantauan peneliti sampai akhir tahun 2019, belum ada satu pun highlight yang menjelaskan tentang program LAZ. Padahal berdasarkan data yang diperoleh selama proses pengembangan, program yang dimiliki LAZ Solopeduli sangat banyak, dan fitur highlight sangat potensial untuk membahas satu per satu.

Keterbatasan LAZ Solopeduli adalah belum adanya sumber daya manusia yang dialokasikan khusus untuk membuat konten multimedia, sehingga penerimaan LAZ terhadap penelitian ini sangat positif. Adapun proyek program yang dipilih adalah "Akikah Peduli". Menurut narasumber, program ini adalah program yang belum populer sehingga membutuhkan strategi lebih untuk mempromosikannya.

2) Genre and Character

Program "Akikah Peduli" ini berhubungan dengan tagline-tagline yang sering dipakai pada media pemasaran terdahulu, dan diteruskan hingga sekarang. Tagline tersebut adalah:

a) Akikah sekaligus bersedekah

b) Akikah bertabur doa yatim dan dhuafa.

Selain itu, ada tiga hal yang ditekankan pada material dasar penyusun animasi, yaitu:

a) Dominasi warna font diambil dari logo (biru dan jingga).

b) Akikah identik dengan kambing, dan bayi.

c) Ukuran, font, dan warna logo wajib mengikuti aturan LAZ.

3) Location and Interface

Pada tahap ini, narasumber Solopeduli menjelaskan secara detail mengenai alur animasi yang dikehendaki. Alur ini dapat dilihat pada Gambar 2. Adapun seluruh desain gambar mengenai "Akikah Peduli" yang pernah disebarkan secara daring atau foto-foto yang mendukung, juga diberikan pada tahap ini.

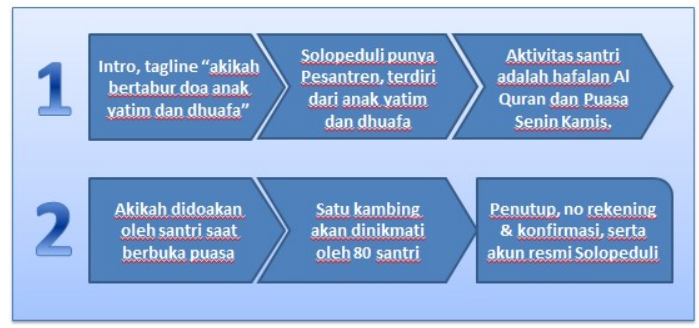

Gambar 2. Alur Akikah Peduli 
4) Plotting and Scripting

Pada penelitian ini, tahap plotting dan scripting dijadikan satu, karena hasil akhir dari pengembangan ini adalah animasi. Hal yang paling rumit dalam membuat animasi adalah peletakan material sesuai dengan gerakan yang dikehendaki, dan mengatur gerakan antar material dapat terlihat harmonis, sehingga tidak terlalu rumit dalam coding. Adapun plotting dilakukan menggunakan alat bantu Adobe After Effect.

\section{5) Production and Testing}

Material yang telah diplot pada layer dan frame, akan menghasilkan animasi. Langkah selanjutnya adalah pemberian musik latar. Apabila sudah selesai dilakukan, maka animasi siap diuji dengan cara mengunggahnya pada Instagram untuk melihat apakah tampilan pada mobile tidak merusak desain animasi yang sesungguhnya. Hasilnya, animasi dapat dijalankan dengan baik pada highlight Instagram. Side by side animasi dapat dilihat pada Gambar 3.

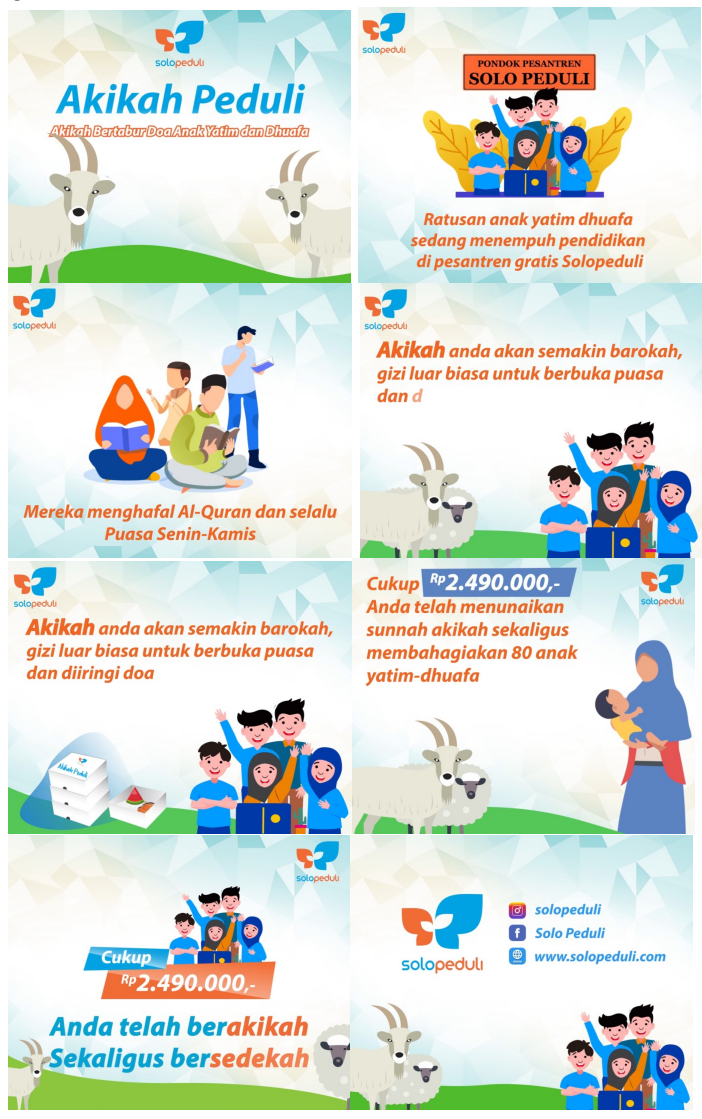

Gambar 3. Side by side Akikah Peduli

\section{c. Metode Sherwood-Rout}

LAZ Solopeduli memilih program "Super Sedekah" untuk diselesaikan dengan metode ini. Adapun tahap pengembangan yang dilakukan adalah sebagai berikut:
1) Project Initation

Program "Super Sedekah" merupakan program rutin yang selalu dipromosikan tanpa membidik waktu tertentu. Program ini berbeda dengan "Akikah Peduli", karena program ini menjelaskan alokasi manfaat dari sebuah nominal yang didonasikan. Tidak ada penekanan alur cerita yang wajib dipatuhi oleh tim pengembang.

2) Specifications

Program ini memiliki logo khusus (di luar logo LAZ Solopeduli) yang telah dipatenkan. Ada 15 program yang akan disebutkan pada program ini, dan pihak LAZ hanya meminta untuk diberikan gambar-gambar pendukung pada side by side animasi (tidak dijelaskan satu persatu).

3) Design

Desain side by side tampilan animasi mulai dikerjakan dengan mempertimbangkan logo "Super Sedekah", dan ketentuan-ketentuan lain seperti penggunaan font, warna, dan ukuran. Peneliti melakukan review bersama dengan LAZ Solopeduli. Hasilnya, terdapat beberapa revisi pada gambar pendukung. Berbeda dengan "Akikah Peduli", alur dari side by side "Super Sedekah" tidak terlalu dikoreksi secara lebih.

\section{4) Production}

Desain yang telah dibuat, kemudian diaplikasikan pada Adobe After Effect. Animasi "Super Sedekah" ini juga terdapat musik latar sebagai pendukung tampilan.

5) Review and Evaluation

Animasi yang telah diproduksi akan didiskusikan bersama LAZ Solopeduli. LAZ dapat memberikan komentarnya terkait gerakan, dan musik latar. Hal yang terjadi dalam tahap ini adalah narasumber LAZ berinisiatif untuk mencoba menambahkan beberapa konten visual pendukung. Akhirnya, pada proses diskusi ini tidak menghasilkan revisi signifikan terhadap konten inti dari animasi profil program "Super Sedekah".

6) Delivery and Implementation

Animasi yang telah disepakati bersama akan diunggah pada highlight Instagram. Side by side animasi dapat dilihat pada Gambar 4. 


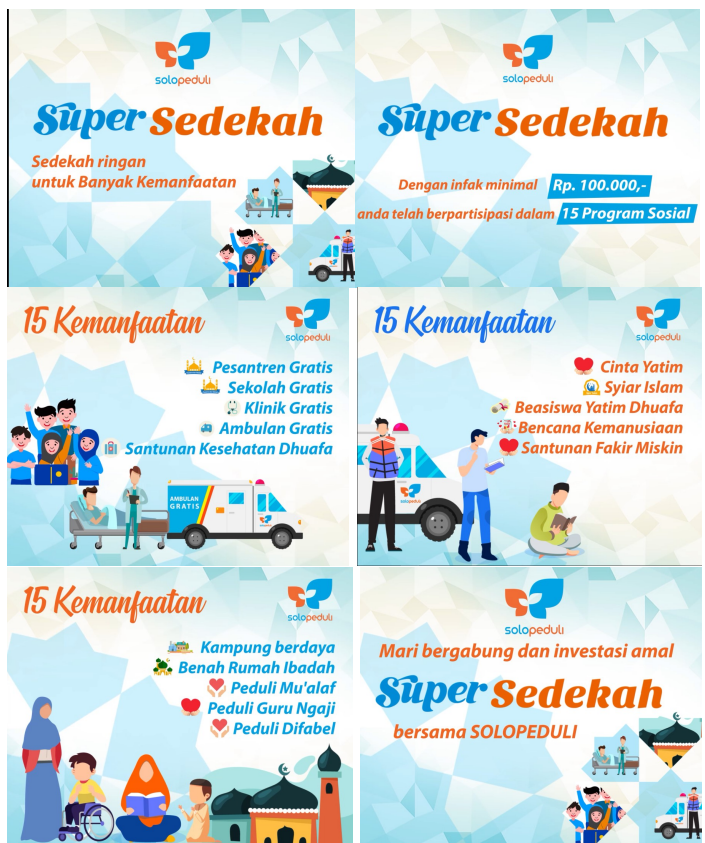

Gambar 4. Side by side Super Sedekah

\section{d. Evaluasi Animasi}

Menurut LAZ Solopeduli, pemilihan metode pengembangan sangat berdampak pada cara LAZ berkomunikasi terkait detail konten. Berkaitan dengan hasil, kedua animasi yang dikembangkan bersama telah sesuai dengan kebutuhan organisasi. Berikut adalah hasil evaluasi bersama LAZ Solopeduli :

Narasumber LAZ Solopeduli,

"Jujur kami tidak begitu memahami sebelumnya, bahwa ada metode pengembangan seperti ini untuk membuat konten multimedia. Kami mendapatkan pembelajaran, khususnya bagaimana kami memahami tahap demi tahap, dan bagaimana kami mempersiapkan diri untuk terjun bersama pada masing-masing tahapnya. Ini sangat menarik, karena kami bisa mempertimbangkan hal ini untuk membuat kontrak-kontrak baru. Sehingga persiapan kami bisa tepat sesuai dengan ekspektasi kami."

\section{Evaluasi Metode Godfrey dan Metode Sherwood-Rout}

Tidak banyak referensi tentang faktor yang mempengaruhi kesuksesan penerapan metode pengembangan multimedia, karena penelitian terdahulu membuat multimedia hanya dengan satu metode. Beberapa peneliti memilih metode Godfrey untuk membuat multimedia promosi atau pengenalan, karena sifatnya yang terstruktur dan mudah untuk dilakukan (Sembiring \& Ompusunggu, 2016; Sinta \& Sembiring, 2017). Sementara Dewanto (2015) menggunakan metode Sherwood-Rout tanpa menjelaskan alasan atau kesimpulan dari penerapan metode tersebut.

Penggunaan metode Godfrey untuk "Akikah Peduli" dan metode Sherwood-Rout untuk "Super Sedekah" adalah tepat. Tidak ada referensi satu pun yang mengatakan metode Godfrey lebih baik daripada metode SherwoodRout, atau sebaliknya. Berdasarkan hasil pengembangan yang dilakukan oleh peneliti, kedua metode ini dapat menjadi metode yang terbaik bagi kasus yang tepat.

Program Akikah Peduli ini memiliki aturan "cerita" sendiri, mulai dari awal sampai akhir, dan terdapat aturan tersendiri mengenai apa yang harus ada sampai bagaimana menceritakannya. Peneliti menilai bahwa program ini sangat tepat untuk dikembangkan dengan metode Godfrey, karena kasus ini sangat memerlukan langkah yang runtut mulai dari Genre and Character, Location and Interface, Plotting, dan Scripting guna memperoleh hasil animasi yang sesuai dengan ekspektasi tanpa harus banyak proses review.

Program "Super Sedekah" merupakan satu program yang menjadi penghubung bagi program-program lain di LAZ Solopeduli. Program ini sebenarnya tidak memiliki aturan "cerita" sendiri, akan tetapi memerlukan beberapa material gambar pendukung yang dapat mewakili list program yang terhubung dengan "Super Sedekah". Peneliti menilai bahwa program ini sangat tepat dikembangkan dengan metode Sherwood-Rout, karena target yang ingin dicapai pada animasi program ini adalah daya tarik visual. Hal ini didukung dengan tahap Review and Evaluation, yang memungkinkan animasi dapat didiskusikan kembali sebelum dipublikasikan.

Hasil pengamatan terhadap kedua metode pengembangan dapat dilihat pada Tabel 2 . Hasil ini dapat digunakan sebagai referensi bagi pengembang multimedia untuk mempertimbangkan metode yang sesuai dengan kasusnya. 
Tabel 2. Perbedaan Fokus Metode

\begin{tabular}{|c|c|c|}
\hline Fokus & Godfrey & Sherwood-Rout \\
\hline Hasil Animasi & $\begin{array}{l}\text { Penekanan } \\
\text { animasi pada } \\
\text { alur animasi } \\
\text { atau cerita. }\end{array}$ & $\begin{array}{l}\text { Penekanan animasi } \\
\text { pada daya tarik } \\
\text { visual. }\end{array}$ \\
\hline Proses Desain & $\begin{array}{l}\text { Proses desain } \\
\text { lama, untuk } \\
\text { mematangkan } \\
\text { konsep alur dan } \\
\text { cerita, kemudian } \\
\text { material } \\
\text { pendukung } \\
\text { berdasarkan } \\
\text { karakteristiknya. }\end{array}$ & $\begin{array}{lr}\text { Proses desain lebih } \\
\text { singkat, karena } \\
\text { material yang } \\
\text { dibutuhkan hanya } \\
\text { gambar pendukung. }\end{array}$ \\
\hline $\begin{array}{l}\text { Ketersediaan } \\
\text { data dan } \\
\text { informasi terkait } \\
\text { aturan. }\end{array}$ & $\begin{array}{l}\text { Organisasi } \\
\text { memiliki data } \\
\text { dan informasi } \\
\text { yang lengkap } \\
\text { mengenai aturan } \\
\text { dan kepatuhan, } \\
\text { didukung oleh } \\
\text { kemampuan } \\
\text { berkomunikasi } \\
\text { yang baik. }\end{array}$ & $\begin{array}{l}\text { Data dan informasi } \\
\text { tidak begitu menjadi } \\
\text { hal yang penting, } \\
\text { sebab tidak ada } \\
\text { aturan yang } \\
\text { mengikat proses } \\
\text { pengembangan } \\
\text { secara signifikan. }\end{array}$ \\
\hline
\end{tabular}

Berdasarkan hasil pengamatan yang dilakukan oleh tim peneliti, ketepatan pemilihan proyek ini juga sangat dipengaruhi oleh sikap LAZ. Hal ini tampak dari peristiwa berikut ini:

1) Respon LAZ Solopeduli sangat positif terhadap penelitian ini, dan LAZ Solopeduli menganggap bahwa penelitian ini akan berdampak pada aktivitas organisasi.

2) Kemampuan LAZ Solopeduli dalam mengungkapkan apa yang menjadi kebutuhan secara detail, sehingga peneliti mampu memperoleh sketsa awal yang tepat tanpa harus banyak proses review.

3) Kelengkapan data dan informasi yang dimiliki oleh LAZ Solopeduli terkait programnya. Hal ini menjadikan referensi dalam pengembangan proyek program sehingga tidak mengalami banyak kesulitan.

\section{KESIMPULAN}

Kesimpulan dari penelitian ini adalah sebagai berikut :

1. Penelitian ini telah menerapkan metode Godfrey untuk "Akikah Peduli" dan metode Sherwood-Rout untuk "Super Sedekah". Hasilnya, baik "Akikah Peduli" maupun "Super Sedekah" telah sesuai dengan kebutuhan LAZ.

2. Penelitian ini telah membedakan metode Godfrey dan metode Sherwood-Rout berdasarkan tiga fokus utama. Tiga fokus tersebut adalah hasil animasi, proses desain, dan ketersediaan data dan informasi terkait aturan. Ketepatan dalam memahami fokus kasus akan menjadikan kedua metode dapat digunakan secara maksimal. Artinya, tepat atau tidaknya sebuah metode pengembangan, dan sesuai atau tidaknya hasil multimedia, tergantung pada organisasi dalam memahami kebutuhan dan situasinya.

3. Dalam kasus ini, sikap lembaga diduga kuat mempengaruhi ketepatan keputusan dalam pemilihan animasi pada metode Godfrey dan metode Sherwood-Rout. Sehingga, penelitian selanjutnya diharapkan mampu untuk membahas kedua metode ini dalam konteks LAZ yang berbeda. Perbedaan skala, iklim organisasi, sikap staf inti, bisa jadi juga berpengaruh dalam pengembangan multimedia. Hal ini sangat menarik untuk dibahas dalam penelitian yang berkelanjutan.

\section{REFERENSI}

Aisyah, R. D. (2010). Rancangan bangun sistem informasi penyaluran dana zakat kapada mustahik: studi kasus: lazis arRahman-Aisyiyah.

Arfan, M., Wilopo, S. A., \& Wahyuni, B. (2010). Effectivnes of Health Education Through Multimedia E-file and Face to Face Method on Teenage Reproductive Health to Improvement of Knowledge about Teenage Reproductive Health. Berita Kedokteran Masyarakat, 26(3), 107-114. https://doi.org/10.1109/WAINA.2013.176

Binanto, I. (2013). Kajian Metode-Metode Pengembangan Perangkat Lunak Multimedia. Jurnal Penelitian, 17(1).

Dara, Y., Kurniadi, D., \& Budayawan, K. (2018). PERANCANGAN APLIKASI PERHITUNGAN ZAKAT MAL, MENENTUKAN WAKTU SHALAT DAN ARAH KIBLAT MENGGUNAKAN GPS BERBASIS ANDROID. Jurnal Vocational Teknik Elektronika Dan Informatika, 2(2).

Dewanto, F. M. (2015). Pengembangan Multimedia Interaktif 3D dengan Structured Methodology Materi Sistem Pencernaan Manusia. Jurnal Informatika Upgris, 1 (1 Juni).

Fatoni, A., \& Puspitasari, N. (2016). PERANCANGAN PENGEMBANGAN SIMULASI SISTEM PROGRAMMING PENYALURAN DANA ZAKAT DI BADAN AMIL ZAKAT KOTA SERANG BERBASIS MULTIMEDIA. PROSISKO: Jurnal Pengembangan Riset Dan Observasi Sistem Komputer, 3(2).

Godfrey, R. (1995). New Wine in Old Bottle: Multimedia Design Methodology. ASCILITE, 95.

Gufroni, A. I., Wisandani, I., \& Sukmawati, H. (2014). Sistem Informasi Unit Pengumpul Zakat Terintegrasi ( Studi Kasus: 
BAZNAS Kota Tasikmalaya ). Jnteti, 3(4), 236-241. ejnteti.jteti.ugm.ac.id/index.php/JNTETI/art icle/view/109

Hackler, D., \& Saxton, G. D. (2007). The strategic use of information technology by nonprofit organizations: Increasing capacity and untapped potential. Public Administration Review, 67(3), 474-487. https://doi.org/10.1111/j.15406210.2007.00730.x

Hartono, S. B. (2018). Membangun Spiritual Capital Muzakki Dari Diferensiasi , Promosi, dan Minat Dalam Berzakat. Jurnal lqtisaduna, 4(2), 154-169.

Haryanto, T., \& Nugroho, S. (2015). Perancangan Video Company Profile Sebagai Media Promosi Perusahaan Pada Pt. Propan Raya Icc Semarang. Jurnal IImiah Komputer Grafis, 8(1), 4652.

Herdiyansyah, E., Satria, E., \& Cahyana, R. (2013). Pengembangan Aplikasi Pendaftaran Muzakki dan Mustahik berbasis Web di Badan Amil Zakat Daerah Kabupaten Garut. Jurnal Algoritma, 10(2), 99-114.

Indonesia, I. A. (2011). Pernyataan Standar Akuntansi Keuangan No 109: Akuntansi Zakat Infak/Sedekah.

Indonesia, P. N. R. (2014). Peraturan Pemerintah Nomor 24 Tahun 2014tentang Pelaksanaan Undang-Undang Nomor 43 Tahun 2007tentang Perpustakaan.

Khair, R. A. (2011). Rancang bangun mobile application informasi zakat berbasis multimedia.

Maimunah, Sunarya, L., \& Nina Larasati. (2012). Media Company Profile Sebagai Sarana PENUNJANG INFORMASI DAN PROMOSI. Creative Communication and Innovative Technology Journal, 5(40), 281-301.

Melin, L., \& Nordqvist, M. (2007). The reflexive dynamics of institutionalization: The case of the family business. Strategic Organization, 5(3), 321-333.

Nordqvist, M., Hall, A., \& Melin, L. (2009). Qualitative research on family businesses: The relevance and usefulness of the interpretive approach. Journal of Management and Organization, 15(3), 294-308.

https://doi.org/10.5172/jmo.2009.15.3.294

Novansyah, A., Sunardi, H., \& Ramadhan, M. (2016). Sistem informasi pengolahan zakat dan infaq pada masjid agung palembang. Jurnal IImiah Informatika Global, 6(1).

Satryadi, A. (2016). ANALISIS PESAN DAKWAH DALAM IKLAN ZAKAT DOMPET DHUAFA KARYA SYAFA' $A T$ $M A R C O M M$. Universitas Islam Negeri Walisongo Semarang.

Sembiring, E. B., \& Ompusunggu, J. (2016). Rancang Bangun Multimedia Interaktif Pembelajaran Alat Musik Tradisional Melayu Menggunakan Metode Godfrey. Prosiding Seminar ABEC Politeknik Caltex Riau Pekan Baru, 7.

Sherwood, C., \& Rout, T. (1998). A structured methodology for multimedia product and systems development. Proceedings of The Australasian Society for Computers in Learning in Tertiary Education (ASCILITE), 617-625.

Sinta, G., \& Sembiring, E. B. (2017). Multimedia Interaktif Untuk Promosi Produk Pada Pegadaian Menggunakan Metode Godfrey,". Jurnal Teknomatika, 9(2).

Suartama, I. K. (2010). Kualitas Pembelajaran Pada Mata Kuliah Media. Jurnal Pendidikan Dan Pengajaran, 43(3), 253262.

Sunarya, Lusyani; Radiyanto; Susanti, E. (2013). ENRICHING COMPANY PROFILE SEBAGAI PENUNJANG MEDIA INFORMASI DAN PROMOSI PADA PERGURUAN TINGGI RAHARJA. CCIT Journal, 7, 77-93. 